\author{
Jacek Kurek \\ https:// orcid.org/0000-0003-1688-4632 \\ Uniwersytet Opolski \\ Instytut Geografii Społeczno-Ekonomicznej i Gospodarki Przestrzennej \\ jacek.kurek@uni.opole.pl
}

\title{
PARTYCYPACJA SPOŁECZNA W KONTEKŚCIE BUDOWY TRASY ŚREDNICOWEJ W OPOLU
}

\begin{abstract}
Abstrakt: Autor artykułu postawił sobie za cel opisanie przebiegu konfliktu przestrzennego oraz analizę procesu partycypacji społecznej w kontekście planowanej budowy trasy średnicowej przebiegającej przez wyspę Pasiekę w Opolu. Posługując się metodą studium przypadku podjęto próbę znalezienia odpowiedzi na pytania: czy władze samorządowe zastosowały "dobre praktyki” postulowane przez organizacje pozarządowe oraz jaką rolę odegrał w nich ruch miejski.

Słowa kluczowe: partycypacja społeczna, konsultacje społeczne, planowanie przestrzenne, trasa średnicowa, Opole.

\section{SOCIAL PARTICIPATION IN THE CONTEXT OF THE PLANNED CONSTRUCTION}

OF THE CROSS-CITY ROUTE RUNNING THROUGH PASIEKA ISLAND IN OPOLE

Abstract: This article aims to describe and analyse the process of spatial conflict and social participation in the context of the planned construction of the cross-city route running through Pasieka Island in Opole. By applying the case study method, an attempt was made to find the answers to the following questions: were the so-called good practices postulated by non-governmental organisations applied and what role was played by an urban movement?

Keywords: social participation, social consultations, spatial planning, cross-city route, Opole.
\end{abstract}

\section{WPROWADZENIE}

Partycypacja społeczna i konsultacje społeczne to terminy, które często pojawiają się $\mathrm{w}$ pracach naukowych dotyczących planowania przestrzennego. Także dlatego, że przygotowywanie projektów „Studium uwarunkowań i kierunków zagospodarowania przestrzennego" oraz „Planu zagospodarowania przestrzennego" objęte jest ustawowym nakazem umożliwienia obywatelom wyrażenia $\mathrm{w}$ tej kwestii uwag, opinii, postulatów i rozwiązań (Ustawa o planowaniu $i$ zagospodarowaniu przestrzennym $z 27$ marca 2003 r., art. 11 i 17). Aktywny udział społeczności lokalnej $\mathrm{w}$ procesie planowania przestrzeni jest zjawiskiem pożądanym i docenianym, szczególnie w krajach Europy Zachodniej. Niestety w naszym kraju zdarza się, że zaangażowanie obywateli traktowane jest przez rządzących $\mathrm{z}$ dystansem (a nawet $\mathrm{z}$ niechęcią), a konsultacje o charakterze opiniotwórczym bywają tak przeprowadzane, aby zrealizować cele władzy. Na niedoskonałość tego narzędzia wskazują Arnstein (2012) i Pröpper (2000), według których służą one jedynie pozornym formom działania. Takiej sytuacji sprzyjają niejednoznaczne przepisy prawne zawarte $\mathrm{w}$ ustawie o planowaniu i zagospodarowaniu przestrzennym. Piszą o tym m.in.: Czarnik (2017), Fiedziukiewicz (2008), Kmieciak (2017), Małecka-Łyszczek (2014), Marchaj (2014), Niżnik-Dobosz (2014) czy Szlachetko (2017).

Otwiera to szerokie pole dla konfliktów o charakterze przestrzennym, których przebieg przez ponad 30 lat opisano w licznych pracach naukowych w Polsce (Grochowska, 2016). Ze względu na przedmiot niniejszej pracy wybrano takie podejście do sporów w gospodarce przestrzennej, które uwzględnia perspektywę społeczną. Zdaniem Dutkowskiego (1995) konflikty mogą występować w kręgu samych eksploratorów dóbr środowiskowych, między 
użytkownikami dóbr środowiskowych a służbami ochrony środowiska, pomiędzy wyrazicielami odmiennych sposobów użytkowania dóbr środowiskowych. Zuziak (1995) zauważa, że uczestnicy biorący udział w rywalizacji o przestrzeń „różnią się zdecydowanie $\mathrm{w}$ swoich celach, interesach, intencjach itp., a w konsekwencji w zachowaniach w odniesieniu do konkretnych zmian $\mathrm{w}$ zagospodarowaniu przestrzennym, a także $\mathrm{w}$ ocenie wpływu tych zmian na wartość środowiska" (Zuziak, 1995, s. 140). Według Dmochowskiej-Dudek (2014) konflikt w przestrzeni materialnej może dotyczyć również wartości niematerialnych, takich jak: tożsamość mieszkańców, poczucie bezpieczeństwa czy wartości estetyczne. Poza tym "konflikt toczący się $\mathrm{w}$ warstwie społecznej zmienia przestrzeń w wymiarze fizycznym i prowadzi do nadania jej nowych wartości, co skutkuje z kolei przemianami przestrzeni społecznej" (Dmochowska-Dudek, 2014, s. 149).

W niniejszej pracy zdecydowano się na zastosowanie metody o charakterze jakościowym i indukcyjnym, opierającej się na studium przypadku (ang. case study). Metoda ta, zaliczana do nurtu metodologii interpretatywnej, polega na szerokim opisie jakiegoś zjawiska społecznego (Lachiewicz, Matejun, 2010), co umożliwia prezentację jego bardziej szczegółowego obrazu, dokładne poznanie zachodzącego przypadku, zjawiska, procesu. Case study ma służyć celom edukacyjnym, umożliwić przeanalizowanie popełnionych błędów, ale także wskazać wzory godne naśladowania. Należy jednak wspomnieć istotne ograniczenie tej metody, jakim jest mała reprezentatywność wyników (Matejun, 2011).

W dorobku naukowym dotyczącym badań nad konfliktami przestrzennymi warto przywołać przykłady prac stanowiących studia przypadku. Między innymi Hajduk (2010) opisała źródła konfliktów $\mathrm{w}$ środowisku przyrodniczym $\mathrm{w}$ gminie Piątnica, a Jabłoński i Mazurkiewicz (2014) - konflikt wokół usytuowania fermy norek w gminie Żórawina, natomiast Tokajuk (2011) przedstawił konflikty przestrzenne na styku istniejącej zabudowy zagrodowej i planowanej zabudowy mieszkaniowej w aspekcie powiększania granic Białegostoku.

Prezentowane $\mathrm{w}$ tym artykule badania pozwoliły na dokonanie charakterystyki działań partycypacyjnych związanych z planami budowy trasy średnicowej przebiegającej przez wyspę Pasiekę w Opolu. Badania oparto przede wszystkim na danych zastanych (ang. desk research), a następnie ich analizie, wzajemnej weryfikacji i scaleniu. Przywołując słowa Webera (1985) trzeba pamiętać, że „wszelkie poznanie rzeczywistości kulturowej [...] jest zawsze poznaniem ze specyficznie wyodrębnionych punktów widzenia." (Weber, 1995, s. 73). Dane zastane to źródła, które nie zostały wywołane przez badacza, lecz stanowią wytwór społeczeństwa gromadzony w celach administracyjnych, naukowych i innych (Angrosino, 2010). Można do nich zaliczyć dokumenty urzędowe (m.in. wnioski kierowane do Urzędu Miasta Opola, RDOŚ, GDOŚ), a także dane ogólnie dostępne i okolicznościowe, takie jak zasoby Internetu w postaci np. dokumentów oraz tekstów prasowych w lokalnej prasie („Nowa Trybuna Opolska”, "Gazeta Wyborcza” - Dodatek opolski).

Celem poznawczym artykułu jest ukazanie konfliktu przestrzennego, który ujawnił się po ogłoszeniu planów budowy trasy średnicowej, przedstawienie związanego z nim procesu partycypacji obywatelskiej oraz znalezienie odpowiedzi na następujące pytania:

1. Jaką rolę $\mathrm{w}$ procesie partycypacji odegrał ruch miejski?

2. Czy w procesie partycypacyjnym, związanym z budową trasy średnicowej przebiegającej przez opolską wyspę Pasiekę, zastosowano tzw. dobre praktyki postulowane przez organizacje pozarządowe?

Celem aplikacyjnym prezentowanej pracy jest wskazanie błędów w przebiegu opisywanej partycypacji społecznej oraz podanie zaleceń co do sposobu przeprowadzenia jej satysfakcjonująco zarówno dla władz samorządowych, jak i społeczności lokalnej.

\section{PARTYCYPACJA SPOŁECZNA - DEFINICJE, FORMY}

Według słownika języka polskiego "partycypacja” (łac. participare) oznacza: współdziałać, angażować się, udzielać, uczestniczyć (Dubisz, 2006, s. 57). Zdaniem Małeckiej-Łyszczek, partycypacja to pojęcie wielowymiarowe, które "swój właściwy kontekst znaczeniowy buduje w powiązaniu $\mathrm{z}$ konkretnym zjawiskiem, do którego ją odnosimy" (Małecka-Łyszczak, 2014, s. 44). Termin ten stosowany jest m.in. przez takie dziedziny nauki, jak: prawo i administracja, politologia, socjologia, psychologia czy zarządzanie.

Partycypacja społeczna (obywatelska) może być rozpatrywana jako forma redystrybucji władzy, mająca na celu dopuszczenie do kręgu decyzyjnego osób wykluczonych (Arnstein, 2012), ale także jako aktywny udział obywateli w procesie podejmowania 
decyzji odnoszących się do funkcjonowania ich społeczności (Olejniczak, 2015).

Według Wójcickiego (2014) partycypacja w ujęciu horyzontalnym jest podstawą społeczeństwa obywatelskiego i obejmuje współdziałanie różnych grup społecznych oraz jednostek zogniskowane wokół określonego przedsięwzięcia. Wyrazem takiego podejścia jest definicja Skalskiego, według którego partycypacja społeczna to "proces porozumienia między jak największą liczbą zainteresowanych mieszkańców, reprezentantami władz i specjalistami, przy czym te trzy grupy traktowane sa jako równorzędni partnerzy" (Skalski, 1996, cyt. za: Siemieński, 2016, s. 81). W ujęciu wertykalnym partycypacja przyjmuje postać zaangażowania się obywateli w działalność decydenta (Wójcicki, 2014). Ta aktywność niedecydentów w życiu publicznym - polegająca na włączaniu się przez nich w działania zainicjowane przez władze publiczne - obejmuje nie tylko udział $\mathrm{w}$ wyborach, referendach czy konsultacjach społecznych, ale także zgłaszanie petycji i skarg (Olejniczak, 2015). Adekwatną do tego ujęcia definicję można znaleźć w poradniku pt. Komunikacja społeczna. Partycypacja społeczna została tam określona jako „udział obywateli w zarządzaniu sprawami społeczności, której są członkami" (Hausner, 1999, s. 13). W niniejszym artykule przyjęto podejście pierwsze.

Nie sposób jednak rozpatrywać partycypacji bez odniesienia się do kwestii władzy. Zwracała na to uwagę Arnstein, uważając partycypację obywatelską za synonim władzy, strategię, „dzięki której wykluczeni [z procesów politycznych i gospodarczych - J.K.] będą mogli decydować o sposobach podziału informacji, o celach politycznych, o alokacji zasobów, działaniu programów społecznych czy kulturalnych" (Arnstein, 2012, s. 13). Co więcej, jak słusznie podkreślają du Wall i Walecka-Rynduch (2012), celem partycypacji jest nie tylko uczestnictwo w decyzjach władzy, ale także zdolność do jej kontrolowania.

Udział obywateli w sprawowaniu władzy to nieodłączny element demokracji i społeczeństwa obywatelskiego. Państwo polskie zadeklarowało wspieranie rozwoju partycypacji obywatelskiej $\mathrm{w}$ takich dokumentach, jak np. „Długookresowa strategia rozwoju kraju. Polska 2030” oraz "Strategia rozwoju kraju 2020". Działania takie powinny być priorytetowe także na poziomie regionalnym i lokalnym (Schimanek, 2015), tym bardziej że partycypacja obywatelska łączy się $z$ efektywizacją zarządzania $\mathrm{w}$ sferze publicznej. $Z$ jednej strony uczy bowiem dialogu i solidaryzmu społecznego, daje wiedzę na temat działania władzy oraz poczucie sprawstwa, włącza wykluczonych społecznie, a $z$ drugiej - legitymizuje decyzje władz oraz poprawia funkcjonowanie administracji publicznej w zakresie rozpoznawania potrzeb i rozwiązywania problemów. Bez wątpienia wzmacnia także relacje na linii władza-obywatele oraz obywateleobywatele (Schimanek, 2015).

Arnstein wyróżnia osiem poziomów partycypacji (schemat poniżej) - przedstawione zostały $\mathrm{w}$ formie drabiny, a kolejne szczeble idące $\mathrm{w}$ górę obrazują zwiększanie się wpływu obywateli na wynik procesu politycznego (Arnstein, 2012, s. 16).

\begin{tabular}{|c|c|c|}
\hline 8 & $\begin{array}{l}\text { Kontrola obywatelska } \\
\text { (przekazanie obywatelom władzy } \\
\text { potrzebnej, aby mogli zarządzać pro- } \\
\text { gramem lub instytucja, odpowiadać za } \\
\text { politykę i sprawy administracyjne) }\end{array}$ & \multirow{3}{*}{$\begin{array}{c}\text { Uspołecznienie } \\
\text { władzy }\end{array}$} \\
\hline 7 & $\begin{array}{l}\text { Delegowanie } \\
\text { (przekazanie mieszkańcom niemalże } \\
\text { całkowitej władzy nad jakimś progra- } \\
\text { mem) }\end{array}$ & \\
\hline 6 & $\begin{array}{l}\text { Partnerstwo } \\
\text { (podział władzy i odpowiedzialności } \\
\text { pomiędzy obywateli i rządzących) }\end{array}$ & \\
\hline 5 & $\begin{array}{l}\text { Ugłaskiwanie } \\
\text { (obywatele mogą doradzać } \\
\text { i planować, ale to władza osądza } \\
\text { słuszność i przydatność ich porad) }\end{array}$ & \multirow{3}{*}{$\begin{array}{c}\text { Działania } \\
\text { pozorne }\end{array}$} \\
\hline 4 & $\begin{array}{l}\text { Konsultacje } \\
\text { (mają być dowodem na to, że dołożo- } \\
\text { no starań, aby zaangażować obywateli } \\
\text { - jednak ich głosy nie są brane pod } \\
\text { uwagę) }\end{array}$ & \\
\hline 3 & $\begin{array}{l}\text { Informowanie } \\
\text { (jednokierunkowy kanał komunikacji: } \\
\text { od urzędników do obywateli) }\end{array}$ & \\
\hline 2 & $\begin{array}{l}\text { Terapia } \\
\text { (leczenie bezsilności jak choroby psy- } \\
\text { chicznej) }\end{array}$ & \multirow{2}{*}{$\begin{array}{c}\text { Brak } \\
\text { uczestnictwa }\end{array}$} \\
\hline 1 & $\begin{array}{l}\text { Manipulacja } \\
\text { (branie udziału w niewiele znaczących } \\
\text { komitetach doradczych) }\end{array}$ & \\
\hline
\end{tabular}

Warto zauważyć, że w drabinie aż pięć szczebli nie jest związanych $z$ faktycznym współuczestnictwem: dwa pierwsze odpowiadają brakowi uczestnictwa, a trzy kolejne działaniom pozornym. 
Tymczasem, aby partycypacja niosła ze sobą korzyści muszą się w nią zaangażować obydwie strony (Schimanek, 2015). Arnstein (2012) zauważa, że możliwości uczestników tego procesu nie są takie same. Jeżeli nie dochodzi do redystrybucji władzy, to partycypacja staje się fasadowa: wszystkie strony zostają wysłuchane, lecz głos wykluczonych nie jest brany pod uwagę $\mathrm{w}$ akcie decyzyjnym.

\section{PLANOWANIE PRZESTRZENNE A PARTYCYPACJA SPOŁECZNA}

Ustawa o planowaniu $i$ zagospodarowaniu przestrzennym (u.p.z.p.) z 27 marca 2003 r. (Dz.U. 2003, nr 80, poz. 717 ze zm.) oraz Ustawa o rewitalizacji z 9 października 2015 r. (Dz.U. nr 2015, poz. 1777 ze zm.) nadają gminom prawo do prowadzenia polityki przestrzennej na danym terenie oraz do uchwalania gminnych opracowań planistycznych (tzw. władztwo planistyczne). W ich treści można odnaleźć przepisy uwzględniające partycypację społeczną w zakresie procedur planistycznych związanych ze sporządzaniem projektu studium uwarunkowań i kierunków zagospodarowania gminy (dokument obligatoryjny), miejscowego planu zagospodarowania przestrzennego (dokument fakultatywny) oraz planu rewitalizacji (dokument fakultatywny). Jednak, jak wskazuje Zachariasz (2014), polskie prawo planowania przestrzennego można raczej zaliczyć do kategorii refleksu prawnego niż publicznego prawa podmiotowego. Oznacza to, że prawo gwarantuje istnienie partycypacji społecznej, która ma przyczyniać się do polepszenia sytuacji obywatela względem państwa, jednak nie daje ona podstaw do skutecznego dochodzenia swoich żądań. Brakuje np. w u.p.z.p. jednoznacznych regulacji dotyczących sposobu rozpatrywania uwag (Piec, 2009). Znacznie lepiej uregulowano te kwestie $\mathrm{w}$ ustawie o rewitalizacji: w przypadku obowiązkowych konsultacji gmina musi (przed nimi i po nich) udostępnić opiniowane dokumenty tak, aby obywatele mogli monitorować wpływ swoich uwag na ich ostateczny kształt.

Innes i Booher (2000, cyt. za: Wójcicki, 2014) wyróżniają cztery modele realizacji założeń planistycznych i interesu zbiorowego: 1) racjonalistyczny, gwarantujący udział społeczności lokalnej w pracach planistycznych jedynie na podstawie zapisów prawa; 2) oparty na wpływach, w którym decyzje planistyczne zapadają zgodnie $\mathrm{z}$ oczekiwaniami grup lobbystycznych i w sposób niejawny; 3) model, w którym istotną rolę odgrywają działania oddolne (ruchy miejskie), czyli takie, kiedy zainteresowani w sposób zorganizowany wyrażają swój protest wobec kontrowersyjnych planów inwestycji; 4) model polegający na współpracy stron; uzupełniony modelem racjonalistycznym służy wypracowaniu wspólnego planu, uwzględniającego interesy wszystkich uczestniczących $\mathrm{w}$ procesie grup. Ten partnerski model jest filarem systemu planowania $\mathrm{w}$ rozwiniętych społeczeństwach obywatelskich (Wójcicki, 2014).

Nawiązują do tego Długosz i Wygnański (2005). Wymieniają oni zasady, które powinny być przestrzegane $\mathrm{w}$ prowadzeniu konsultacji społecznych: partnerzy instytucjonalni i pojedynczy obywatele uczestniczą w konsultacjach na równych prawach, konsultacje powinny przedstawiać rzetelne opinie i rozwiązania, uwzględniać interesy ogólne oraz stosować się do „ducha prawa”, a nie wyłącznie jego litery. Herbst (2014) dodaje kilka warunków powodzenia partycypacji, w szczególności: podejmowanie spraw istotnych dla społeczności $\mathrm{w}$ odpowiednim momencie, najlepiej już na etapie projektowania. Wszystkie te zalecenia mają jednak wymiar wyłącznie postulatywny.

Tymczasem wiele wskazuje na to, że polski system planowania jest oparty przede wszystkim na podejściu racjonalistycznym. Billert (2013), porównując go $z$ mechanizmami zachodnimi, używa określeń: tradycyjny, industrialistyczny oraz biurokratyczno-proceduralny. Jego zdaniem, brak obowiązku korzystania z szerokiego zakresu partycypacji społecznej powoduje, że społeczność lokalna zostaje właściwie wyłączona $\mathrm{z}$ procesów planistycznych, co w konsekwencji prowadzi do wyzbywania się przez polskie miasta społeczno-politycznej podmiotowości.

Niektórzy badacze zauważają również, że w procesie planowania przestrzennego władze samorządowe sięgają często po działania pozorowane. Sytuację tę trafnie podsumowuje Sadura (2012, s. 42): „Procesy pseudopartycypacyjne, których efekt stanowi zmanipulowanie obywateli lub wzbudzenie $\mathrm{w}$ nich nadziei i pozostawienie bez wsparcia i narzędzi pozwalających kontynuować dzieło rozpoczęte przez partycypacyjny desant z odległej aglomeracji, prowadzą do erozji lokalnego kapitału społecznego". Nadal zwycięża przekonanie, że jedynie eksperci są w stanie podejmować odpowiedzialne decyzje i opracowywać najbardziej adekwatne plany (Piec, 2009). 
Pisząc o partycypacji w planowaniu przestrzennym warto również wspomnieć o drugiej stronie medalu, mianowicie o słabej kondycji obywatelstwa w polskim społeczeństwie. Chociaż od kilkunastu lat jest obserwowany pewien wzrost zainteresowania mieszkańców kwestiami urbanistycznymi czy architektonicznymi - co prawdopodobnie wiąże się z pojawieniem tzw. nowego mieszczaństwa, czyli świadomych swoich praw mieszkańców miast (Jadach-Sepioło, 2018), czy z aktywnością ruchów miejskich (Mikos, 2014) - to jednak większość obywateli do tematyki planowania przestrzennego podchodzi obojętnie. Kikosicka (2014) uważa, że $\mathrm{u}$ podłoża tej inercji społecznej w Polsce leżą zakorzenione historycznie postawy braku zaufania, niechęci do współpracy z rządzącymi i lęku przed manipulacją.

Na konieczność odejścia od ustawowego minimum w zakresie partycypacji społecznej oraz potrzebę zwiększenia udziału obywateli $\mathrm{w}$ procedurach planistycznych i otwarcia się na projekty społeczne zwracają uwagę reprezentanci Towarzystwa Urbanistów Polskich. Jak zauważa jego prezes (Kolipiński, 2014, s. 6):

O prawo uczestnictwa w "grze o miasto" upominają się już nie tylko właściciele nieruchomości, deweloperzy czy działacze ekologiczni, ale także pojawiające się coraz liczniej stowarzyszenia i organizacje [...] Coraz częściej chcą one aktywnie uczestniczyć w procesie przekształcania przestrzeni miejskich, zgłaszając swoje pomysły i alternatywne rozwiązania. To jakościowo nowe zjawisko stawia przed samorządami miejskimi, administracją, ale także przed [...] urbanistami nowe wyzwania. [...] Dlatego musimy szukać odpowiedzi na szereg pytań z tym związanych: Jak być partnerem dla organizacji społecznych i ruchów miejskich? Jakie stosować metody planowania, żeby było ono otwarte na dialog? [...] Czy obowiązujące przepisy dają wystarczające podstawy do społecznej partycypacji w planowaniu przestrzennym?

\section{CHARAKTERYSTYKA OBSZARU BADAŃ}

Obecnie w Opolu przez rzekę Odrę można przejechać samochodem tylko za pomocą trzech przepraw - wliczając w nie most na obwodnicy (rys. 1). Kontrowersje dotyczące budowy trasy średnicowej w Opolu odnoszą się do planu jej przebiegu przez wyspę Pasiekę. W niniejszym artykule trasę średnicową określono jako wchodzącą w skład układu komunikacyjnego miasta przelotową drogę samochodową lub kolejową, która jest przeprowadzona przez dzielnice miasta $w$ taki sposób, aby powiązać jego centralną strefę (śródmieście) z suburbiami. Celem jest usprawnienie transportu miejskiego.

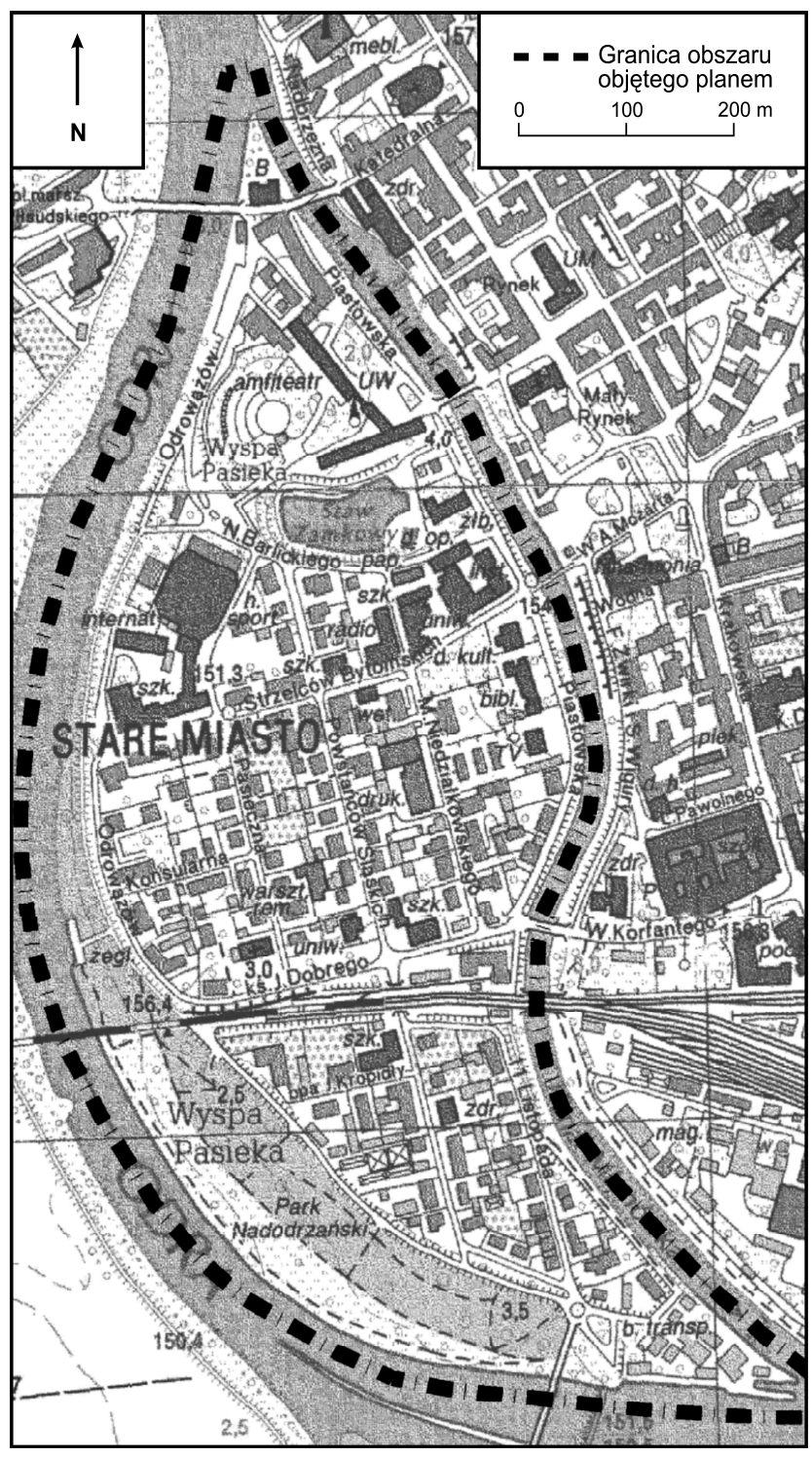

Rys. 1. Granice obszaru wyspy Pasieka w Opolu Źródło: Załącznik do Uchwały nr LXII/ 695/06 Rady Miasta Opola z 6 kwietnia 2006 r.

Opolska wyspa Pasieka powstała w 1600 r., kiedy wskutek powodzi rzeka Odra zmieniła swój bieg (Adamska, 2016). W 1824 r., w okresie panowania pruskiego, zlokalizowano na niej kolonię Wilhelmsthal, co dało asumpt do rozwoju budownictwa willowego (m.in. Willa pod Wilkiem, Willa Academica - nazwa współczesna) oraz utworzenia dużego parku, noszącego obecnie nazwę Nadodrzański (fot. 1). W 1891 r. kolonia znalazła się w granicach Opola (Adamska, 2016). 


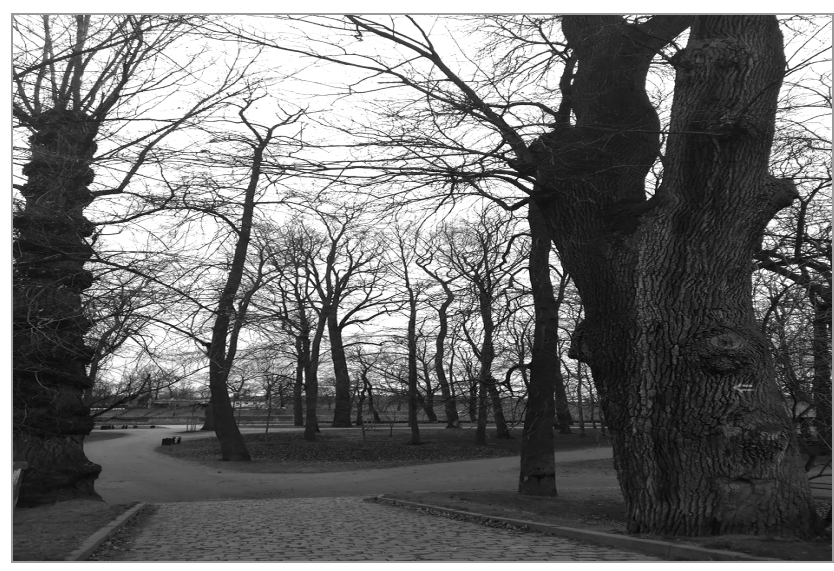

Fot. 1. Fragment Parku Nadodrzańskiego Źródło: J. Kurek

Współcześnie w tej części miasta znajdują się takie obiekty, jak np. Ostrówek (miejsce, w którym odkryto ślady po średniowiecznym grodzie obronnym Opolan), Wieża Piastowska, staw i park zamkowy (pozostałości po rozebranym w latach 30. XX w. Zamku Piastowskim), Amfiteatr Tysiąclecia, modernistyczny kompleks dawnej siedziby rejencji opolskiej (obecnie siedziba urzędów wojewódzkiego i marszałkowskiego), budynek byłego Konsulatu Polskiego w Niemczech, Konsulat Republiki Federalnej Niemiec, uczelnie i placówki naukowe, biblioteki, siedziby mediów itd. (Adamska, 2016).

Przez wyspę Pasiekę, w okolicach Parku Nadodrzańskiego, przebiega most kolejowy (fot. 2). Docelowo Polskie Koleje Państwowe zamierzają zbudować tam drugi, natomiast planowana samochodowa trasa średnicowa miałaby przebiegać trzecim mostem. Wszystkie trzy przeprawy będą położone obok siebie.

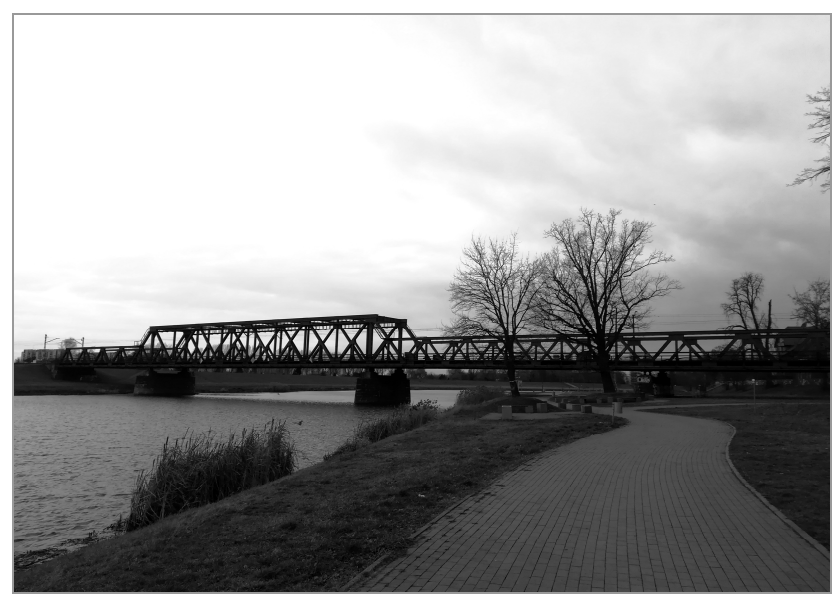

Fot. 2. Most kolejowy, wzdłuż którego ma przebiegać trasa średnicowa przez wyspę Pasiekę w Opolu Źródło: J. Kurek
Jeszcze przed II wojną światową liczbę mostów przez rzekę uznawano za niewystarczająca, dlatego planiści niemieccy zgłosili projekt stworzenia trasy średnicowej przebiegającej przez wyspę Pasiekę. Ze względu na wysokie koszty i problemy techniczne nie doczekał się on realizacji. Ponownie pomysł ten zgłoszono w okresie Polski Ludowej w 1948 r. (Janowski, 2017c).

Omawiane założenie komunikacyjne można odnaleźć w kolejnych planach ogólnych Opola z lat: 1956, 1969, 1986, oraz 1993, a także w "Studium uwarunkowań i kierunków zagospodarowania przestrzennego Opola" z 2001 r. W 2005 r. oraz w 2010 Rada Miasta Opola uchwalała zmiany tego dokumentu. W aktualnym studium z 2010 r. zarezerwowano tereny na przebieg trasy średnicowej przez Pasiekę, którą zaliczono do kategorii „ważniejsze drogi w śródmieściu”. Zdecydowano również, że będzie to połączenie o niższych parametrach - droga lokalna. Jej zadaniem ma być przejęcie ruchu osobowego, co umożliwi rozłożenie go trzema korytarzami drogowymi (obecnie są dwa) pomiędzy wschodnią i zachodnią część miasta. Droga średnicowa została ujęta również $\mathrm{w}$ najnowszym studium z 2018 r. (fot. 3).

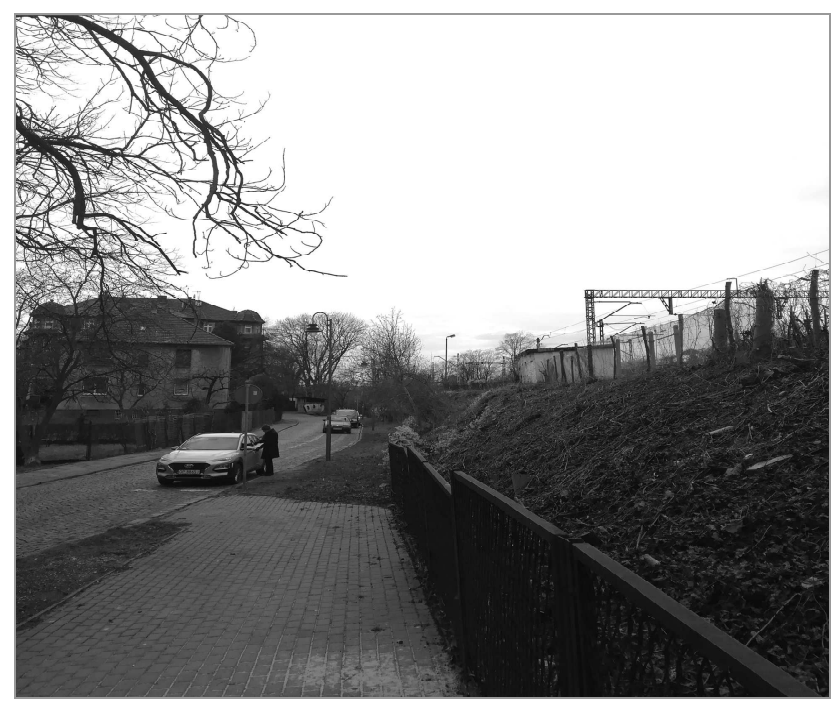

Fot. 3. Planowana droga średnicowa ma przebiegać bardzo blisko zabytkowych budynków na wyspie Pasiece Źródło: J. Kurek

Gdy w ostatnim czasie starania wybudowania samochodowej trasy średnicowej przez wyspę Pasiekę nabrały realnego charakteru i tempa, w sporze dotyczącym projektu budowy tej przeprawy, starly się ze sobą dwie grupy - zwolenników i przeciwników: 


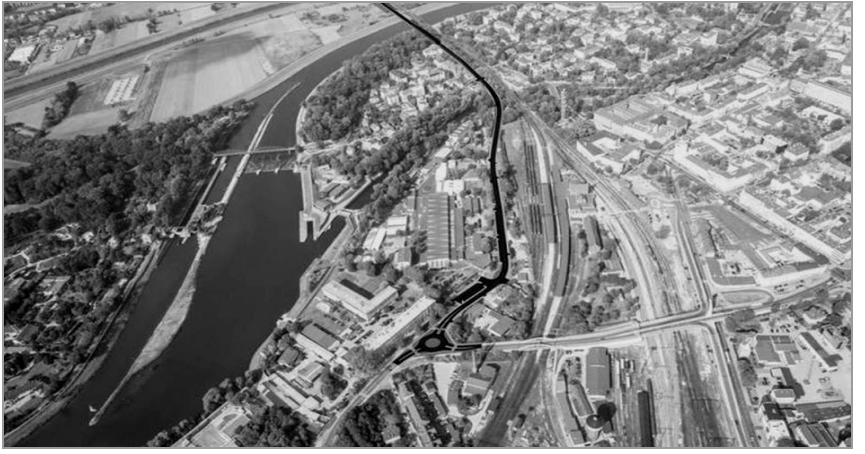

Fot. 4. Planowany przebieg trasy średnicowej przez wyspę Pasiekę w Opolu Źródło: bip.um.opole.pl

- pierwsza: Urząd Miasta Opola, Miejski Zarząd Dróg, powołani eksperci, strażacy, ratownicy medyczni, większość rad dzielnic oraz przeważająca część mieszkańców Opola, którzy w konsultacjach społecznych poparli projekt (fot. 4 i 5);

- druga: stowarzyszenie Komitet Obrony Pasieki - Miasto dla Ludzi, eksperci (architekci, planiści, ekolodzy - znaczna ich część jest członkami KOP - Miasto dla Ludzi), organizacje ekologiczne ( $w$ tym Stowarzyszenie Technologii Ekologicznych "Silesia”), Stowarzyszenie Rowerowe Piasta, parafia ewangelicko-augsburska oraz wspólnoty mieszkaniowe, czyli właściciele budynków zlokalizowanych w pobliżu planowanej inwestycji, naukowcy i społecznicy, inni mieszkańcy wyspy Pasieka oraz ta część mieszkańców Opola, która w konsultacjach głosowała przeciwko projektowi.

\section{KONFLIKT W SPRAWIE TRASY ŚREDNICOWEJ W OPOLU - KALENDARIUM WYDARZEN (OPRACOWANIE NA PODSTAWIE ARTYKUŁÓW W „NOWEJ TRYBUNIE OPOLSKIEJ” I „GAZECIE WYBORCZEJ”)}

2010 r. Tereny na budowę trasy średnicowej zostają uwzględnione $\mathrm{w}$ "Studium uwarunkowań i kierunków zagospodarowania przestrzennego Opola" z 2010 r. (Uchwała nr LXXI/745/10 Rady Miasta Opola z 26 sierpnia 2010 r.).

2011 r. Władze miasta zlecają przygotowanie koncepcji trzech tras: 1) przez wyspę Bolko (na której znajduje się park miejski $\mathrm{z}$ alejami i trasami widokowymi oraz zoo), 2) przez wyspę Pasiekę

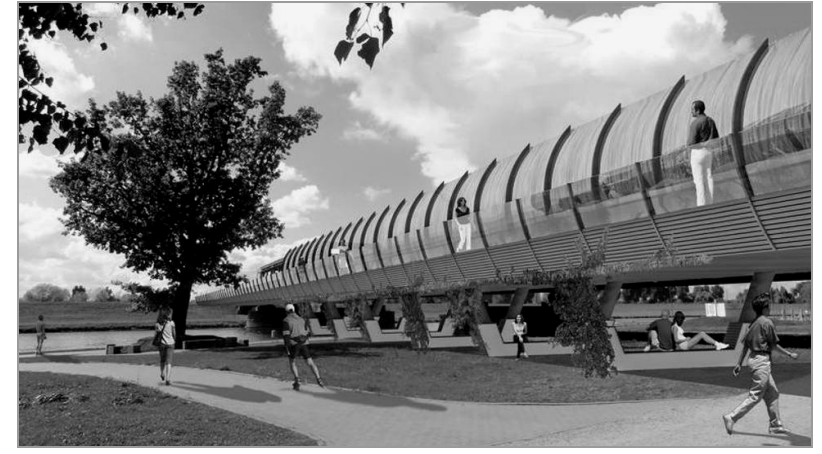

Fot. 5. Wizualizacja planowanej trasy średnicowej przez wyspę Pasiekę w Opolu

(wiadukt na terenie Parku Nadodrzańskiego) Źródło: bip.um.opole.pl

(przedwojenna zabudowa willowa, Park Nadodrzański), oraz 3) fragmentu obwodnicy południowej. Każda z trzech koncepcji ma być zaprezentowana $\mathrm{w}$ trzech wariantach.

Grudzień 2013 r. Do Regionalnej Dyrekcji Ochrony Środowiska (RDOŚ) zostaje złożony raport o oddziaływaniu na środowisko przedsięwzięcia polegającego na budowie trasy średnicowej $\mathrm{w}$ ramach zadania: „Budowa przeprawy przez rzekę Odrę wraz z drogami dojazdowymi i obiektami umożliwiającymi włączenie do układu komunikacyjnego miasta Opola".

2014 r. Treść raportu jest uzupełniana po kolejnych wezwaniach RDOŚ.

Styczeń 2015 r. Po uzyskaniu informacji, że RDOŚ nie wyda pozytywnej opinii, władze miasta odstępują od budowy drogi przez Bolko. Zaczęto promować trasę przez Pasiekę $\mathrm{w}$ wariancie po południowej stronie torów. Do ratusza trafiają pierwsze protesty mieszkańców zwracających uwagę na zwiększenie poziomu hałasu oraz dodatkową emisję spalin i pyłu.

Lipiec 2015 r. RDOŚ organizuje publiczną dyskusję na temat planowanej drogi. Pomysł trasy średnicowej przez Pasiekę krytykują niektóre partie polityczne (Prawo i Sprawiedliwość, Platforma Obywatelska), a także Razem dla Opola - koalicyjny klub w Radzie Miasta (Janowski, 2015b). Przeciwnicy budowy drogi średnicowej organizują protest, w którym bierze udział około 400 osób. Większość podpisuje się pod protekstem do RDOŚ (Janowski, 2015c). Podpisy zbierają także zwolennicy takiego przebiegu trasy średnicowej, przede wszystkim rad dzielnic: Szczepanowice, Wójtowa Wieś, Zaodrze, Groszowice. Stworzono specjalną stronę internetową z przekazem poparcia budowy średnicówki przez Pasiekę. „Nowa Trybuna Opolska” organizuje debatę 
pod hasłem: „Po co miastu droga, której sam pomysł powoduje, że opolanie protestują na ulicy?"

Niedługo po pierwszych protestach ulicznych osoby przeciwne budowie trasy średnicowej przecinającej Pasiekę powołują do życia stowarzyszenie zwykłe pod nazwą Komitet Obrony Pasieki - Miasto dla Ludzi (KOP - Miasto dla Ludzi). Wielu z członków stowarzyszenia to eksperci z zakresu urbanistyki, architektury, ekologii itd. Począwszy od lipca 2015 r. stowarzyszenie zorganizowało kilka protestów mieszkańców oraz happeningów. Występowało także o opinie dotyczące drogi średnicowej do bardzo wielu instytucji, m.in. Wojewódzkiego Konserwatora Zabytków, Komisji ds. Bezpieczeństwa Ruchu Drogowego przy Wydziale Infrastruktury Technicznej i Gospodarki Komunalnej Urzędu Miasta Opola, Ministerstwa Kultury i Dziedzictwa Narodowego, Narodowego Instytutu Dziedzictwa, Regionalnego Zarządu Gospodarki Wodnej we Wrocławiu, Komendy Miejskiej Państwowej Straży Pożarnej, Państwowego Powiatowego Inspektora Sanitarnego w Opolu oraz dyrekcji PKP Polskich Linii Kolejowych S.A. Poza tym KOP - Miasto dla Ludzi skierował pisma do Prezydenta Miasta Opola, radnych miasta Opola, Marszałka Województwa Opolskiego, radnych województwa opolskiego i wojewody. W 2016 r. KOP - Miasto dla Ludzi wzięło udział na prawach strony $\mathrm{w}$ postępowaniu $\mathrm{w}$ sprawie wydania decyzji o środowiskowych uwarunkowaniach dla budowy trasy średnicowej. Wraz $\mathrm{z}$ innymi podmiotami stowarzyszenie odwołało się od decyzji RDOŚ i do chwili obecnej toczy się postępowanie środowiskowe w Generalnej Dyrekcji Ochrony Środowiska.

Wrzesień 2015 r. Ratusz publikuje wizualizacje ukazujące, jak nowa droga wkomponuje się w otoczenie Parku Nadodrzańskiego i wyspy Pasieka (później przedstawiciel organizacji ekologicznej wykaże, że przedstawione na ilustracjach piękne drzewa de facto przeznaczone są do wycięcia). Projekt Ratusza popierają służby pożarnicze i medyczne. Władze miasta organizują spotkania z mieszkańcami 14 dzielnic. Przeciwnicy inwestycji domagają się, aby na spotkaniach prezentować także ujemne skutki inwestycji. Wojewódzki Konserwator Zabytków przedstawia negatywne stanowisko odnośnie do drogi średnicowej biegnącej przez wyspę Pasiekę.
Październik 2015 r. W związku z zaplanowanymi przez Ratusz konsultacjami trwa ożywiona akcja informacyjna obu stron sporu. Miasto zainwestowało w kampanię (spot, ulotki, reklama) około 15 tys. zl, druga strona znacznie mniej, jednak wydrukowała 10 tys. ulotek i zleciła druk artykułu w „Nowej Trybunie Opolskiej”. Kampania toczyła się także w Internecie (Janowski, 2015h). Organizują się również zwolennicy drogi średnicowej przez Pasiekę, którzy planują blokadę Mostu Piastowskiego w Opolu (Janowski, 2015f). Ostatecznie nie doszło do niej, bo wydarzenie zostało zbyt późno zgłoszone i zamiast tego rozdawano opolanom ulotki (Janowski, 2015k). Projekt drogi na Pasiece oraz planowany przebieg obwodnicy południowej popiera też Komisja ds. Ocen Oddziaływania na Środowisko. Na zlecenie RDOŚ powstaje ekspertyza dotycząca oddziaływania planowanej drogi średnicowej przez Pasiekę. Dr Ryszard Kowalczyk postuluje w niej zastosowanie tunelu dźwiękochłonnego (Janowski, 2015h). W ślad za tym drogowcy modyfikują koncepcję drogi średnicowej na Pasiece, proponują zmianę kształtu ekranów, ich podwyższenie (do wysokości $3 / 4$ ) oraz umożliwienie wentylacji (Janowski, 2015h). Łącznie na przygotowania do budowy trasy na Pasiece Opole wydało już ponad 198 tys. zł (Janowski, 2015i).

25 października 2015 r. W Ustawie z 8 marca 1990 r. o samorzadzie gminnym zaznaczono, że w przypadkach przewidzianych ustawą oraz $w$ innych sprawach ważnych dla gminy mogą być przeprowadzane na jej terytorium konsultacje $\mathrm{z}$ mieszkańcami gminy. $\mathrm{Na}$ tej podstawie Prezydent Miasta Opola zarządza konsultacje społeczne w formie głosowania. Przy okazji wyborów parlamentarnych mieszkańcy miasta mogli się wypowiedzieć za pomocą ankiet, wyłożonych w 47 punktach konsultacyjnych utworzonych w siedzibach stałych obwodów głosowania dla miasta Opola (Zarządzenie Prezydenta Miasta nr OR-I.0050.457.2015 z 2.09.2015), w sprawie budowy nowej przeprawy przez Odrę. Prawidłowość oddanych głosów kontrolowano na podstawie numeru PESEL albo imienia i nazwiska wraz z adresem zamieszkania. Można było zagłosować również za pośrednictwem Internetu. Pytania, na które należało odpowiedzieć, brzmiały następująco:

1. „Czy uważa Pan/Pani, że miasto powinno wybudować nowy most przez Odrę, który bę- 
dzie częścią trasy średnicowej łączącej Zaodrze z Centrum?"

2. "Czy uważa Pan/Pani, że miasto powinno wybudować nowy most przez Odrę, który będzie częścią obwodnicy południowej łączącej południową część miasta $\mathrm{z}$ obwodnicą północną przy rondzie na ul. Strzeleckiej?"

3. Która $z$ tych inwestycji powinna być realizowana jako pierwsza?

W ramach konsultacji wypełniono 23445 ankiet (z czego 23102 - w punktach konsultacyjnych, a 343 za pośrednictwem portalu internetowego). 82\% głosujących opowiedziało się za powstaniem drogi (18\% było przeciwnego zdania), która przetnie wyspę Pasiekę, natomiast obwodnicę południową poparło $90 \%$ opolan $(10 \%$ odrzuciło ten wariant). Najistotniejsza była jednak odpowiedź na pytanie trzecie, odnoszące się do tego, która z inwestycji powinna być przeprowadzona najpierw. Aż 63\% osób (12 232 głosy) opowiedziało się za trasą średnicową. Pierwszeństwo obwodnicy południowej dało 37\% mieszkańców (7254 głosy). Wynik głosowania okazał się zbieżny z deklarowanymi zamiarami władz Opola i chociaż nie był on wiążący, stał się ważnym argumentem $\mathrm{w}$ rozmowach $\mathrm{z}$ protestującymi mieszkańcami Pasieki.

Komitet Obrony Pasieki - Miasto dla Ludzi zwrócił się do Prezydenta Opola (13.01.2015) o unieważnienie konsultacji społecznych. $\mathrm{W}$ uzasadnieniu podał m.in.: ograniczenie wyboru do dwóch najmniej korzystnych opcji przeprawy, skonfliktowanie interesariuszy i zmuszenie do wyboru mniejszego zła, brak kontekstu i celowości konsultowanych projektów, braki i sprzeczności $\mathrm{w}$ dokumentacji, nieoczekiwane zmiany już w trakcie jednostronnie prowadzonej kampanii „informacyjnej”. Zastrzeżenia Komitetu zostały odrzucone jako bezzasadne (12.02.2016), gdyż w Uchwale nr XLI/424/04 Rady Miasta w sprawie zasad i trybu przeprowadzania konsultacji z mieszkańcami miasta Opola nie przewidziano możliwości unieważnienia konsultacji.

Listopad 2015 r. Do Urzędu Miasta wpływają kolejne alternatywne propozycje lokalizacji przepraw przez Odrę (Janowski, 2015j).

Lipiec 2016 r. Przeciwnicy budowy trasy organizują happening w Parku Nadodrzańskim. Na drzewach wywieszono tekturowe postacie urzędników Ratusza (w tym prezydenta i wiceprezydenta Opola) i Miejskiego Zarządu Dróg (MZD). Zebrano około 500 podpisów osób sprze- ciwiających się budowie trasy. Po trzech latach analizy RDOŚ wydaje 5.07.2016 r. decyzję o środowiskowych uwarunkowaniach zgody na realizację przedsięwzięcia. Między innymi zalecono stały monitoring środowiska i budynków znajdujących się blisko trasy, budowę 20 specjalnych schronów $\mathrm{w}$ celu ochrony np. nietoperzy, nadzór ornitologa. RDOŚ zastrzegł również, że miasto będzie musiało jeszcze raz przejść procedurę środowiskową dotyczącą gotowego projektu. Odwołania od decyzji RDOŚ składają m.in. ekolodzy ze Stowarzyszenia Technologii Ekologicznych "Silesia”, mieszkańcy zrzeszeni w Komitecie Ochrony Pasieki, dwie kancelarie adwokackie reprezentujące kilka wspólnot mieszkaniowych oraz firma OzasEsab, która będzie sąsiadowała $\mathrm{z}$ nową trasą (Guzik, 2018). Przeciwko średnicówce przebiegającej przez wyspę Pasiekę występuje również Towarzystwo Przyjaciół Komunikacji Miejskiej (Janowski, 2015a).

Styczeń 2017 r. Na terenie przyszłej średnicówki usunięte zostają dwa drzewa. Wzbudza to obawy, że miasto zaczyna działać metodą faktów dokonanych.

Kwiecień 2017 r. Drogowcy nie będąc pewni, czy wydana przez RDOŚ decyzja środowiskowa zostanie utrzymana przez Generalną Dyrekcję Ochrony Środowiska (GDOŚ), nie ogłaszają przetargu na projekt drogi (Janowski, 2017a).

Czerwiec 2017 r. 25 naukowców i społeczników zajmujących się sprawami przyrody apeluje o odstąpienie od budowy trasy średnicowej przebiegającej przez Wyspę Pasiekę (Janowski, 2017b).

Wrzesień 2017 r. GDOŚ ma wątpliwości co do budowy trasy przez Pasiekę i żąda kilkudziesięciu różnego rodzaju uzupełnień (Janowski, 2017d).

Kwiecień 2018 r. GDOŚ zawiesza do jesieni postępowanie w sprawie budowy trasy i nowego mostu na Odrze. Ma to dać czas drogowcom na przygotowanie odpowiedzi na zarzuty ekologów i mieszkańców (Janowski, 2018).

Wrzesień 2019 r. Urząd Miasta wnioskuje do GDOŚ o wznowienie postępowania środowiskowego (Guzik, 2019).

Argumentacja stron konfliktu. Zwolennicy i przeciwnicy budowy drogi średnicowej przez wyspe Pasiekę, biorący udział w konflikcie, wspierali swoje stanowiska argumentami, z których najważniejsze przedstawione zostały $\mathrm{w}$ tab. 2 . 
Tab. 2. Argumenty zwolenników i przeciwników projektu budowy trasy średnicowej na wyspie Pasieka w Opolu

\begin{tabular}{|c|c|c|}
\hline \multirow{2}{*}{$\begin{array}{l}\text { Charakter } \\
\text { argumentu }\end{array}$} & \multicolumn{2}{|c|}{ Argumenty w sprawie projektu } \\
\hline & władz i jego zwolenników & jego przeciwników \\
\hline Formalnoprawny & $\begin{array}{l}\text { - Konsultacje są prawomocne i nie ma procedury, } \\
\text { aby je unieważnić. } \\
\text { - RDOŚ wydała pozytywną decyzję o środowi- } \\
\text { skowych uwarunkowaniach zgody na realizację } \\
\text { przedsięwzięcia. } \\
\text { - Średnicówka może być zbudowana na podsta- } \\
\text { wie specustawy ze względu na ważny interes } \\
\text { społeczny. }\end{array}$ & $\begin{array}{l}\text { - Konsultacje zostały przeprowadzone niezgodnie z pra- } \\
\text { wem oraz zasadami ich organizowania: akcja propa- } \\
\text { gandowa Ratusza oparta była na dezinformacji (nie- } \\
\text { aktualny wariant trasy, pokazano jedynie zalety). } \\
\text { - Decyzja środowiskowa RDOŚ naruszyła przepisy pra- } \\
\text { wa: m.in. nie rozpatrzono całego materiału dowodowe- } \\
\text { go, zaakceptowano niewystarczającą i niespójną treść } \\
\text { raportu, niedostatecznie uzasadniono, dlaczego plano- } \\
\text { wany do realizacji wariant trasy ma być najkorzystniej- } \\
\text { szy dla środowiska (odwołanie do GDOŚ, 2016). } \\
\text { - Jak przyznał inwestor, pozostałe warianty trasy śred- } \\
\text { nicowej przez Pasiekę były nieracjonalne (co narusza } \\
\text { art. } 66 \text { ust. } 1 \text { pkt } 5 \text { u.o.o.ś), gdyż ich realizacja dopro- } \\
\text { wadziłaby do całkowitej niedrożności układu komu- } \\
\text { nikacyjnego miasta (Raport STE „Silesia”). } \\
\text { - Zagęszczenie sieci dróg samochodowych nie stanowi } \\
\text { ważnego interesu społecznego. }\end{array}$ \\
\hline $\begin{array}{l}\text { Komunikacyjno- } \\
\text {-techniczny }\end{array}$ & \begin{tabular}{|l} 
- Lokalne potrzeby komunikacyjne muszą być roz- \\
patrywane nie tylko w skali Pasieki, ale w szer- \\
szym obszarze powiązań. \\
- Nastąpi poprawa warunków ruchu w centrum \\
Opola poprzez odciążenie skrzyżowan ulic, \\
zmniejszenie natężenia ruchu. \\
- W przyjętym wariancie IIA średnicówka ma być \\
drogą lokalną (klasa L1/2), jednoprzestrzenną \\
o dwóch pasach ruchu (po jednym w dwóch kie- \\
runkach), dopuszczalnej prędkości $40 / 50 \mathrm{~km} / \mathrm{h}$, \\
jezdnia o szerokości 6 m plus ciąg pieszo-rowe- \\
rowy. Nie zakłada się ruchu samochodów cię- \\
żarowych i autobusów na planowanej trasie. \\
- Trasa średnicowa upłynni ruch, skróci czas prze- \\
jazdu do kampusu Politechniki Opolskiej oraz \\
dzielnic, które są oceniane jako rozwijające się \\
najszybciej (Wójtowa Wieś, Szczepanowice).
\end{tabular} & \begin{tabular}{|l} 
- Budowa trasy średnicowej jest sprzeczna z ideą zrów- \\
noważonego transportu. Trasa spowoduje przeniesie- \\
nie korków z jednego miejsca w drugie. Opole fawo- \\
ryzuje samochody osobowe, tymczasem na całym \\
świecie samochody wyprowadza się poza centra miast. \\
- Wariant IIA nie był przewidziany w „Studium uwa- \\
runkowań i kierunków zagospodarowania przestrzen- \\
nego Opola” w $2010 \mathrm{r}$. i w „Miejscowym planie zagos- \\
podarowania przestrzennego wyspy Pasieki” w $2007 \mathrm{r}$. \\
nie przewidziano rezerwy terenu pod trasę średnicową. \\
- Nieprawdą jest, że pozostałe przeprawy w centrum \\
miasta są obciążone w $100 \%$ - wykonane na zlecenie \\
inwestora pomiary ruchu w 2010 r., a następnie w 2015 \\
wykazały odciążenie w tym okresie gównego prze- \\
jazdu przez Odrę o 8 tys. pojazdów na dobę (pomimo \\
zwiększenia się ruchu wewnątrzmiejskiego oraz licz- \\
by zarejestrowanych pojazdów).
\end{tabular} \\
\hline Ekonomiczny & $\begin{array}{l}\text { - Projekt trasy będzie kosztować } 4 \mathrm{mln} \text { zł, ale } \\
\text { wstępne koszty całości inwestycji szacowane są } \\
\text { na } 120 \mathrm{mln} \text { zł. Warto je wydać w celu udroż- } \\
\text { nienia ruchu w mieście. }\end{array}$ & $\begin{array}{l}\text { - Zbyt duże koszty za budowę jednojezdniowej drogi } \\
\text { o długości 1,8 km, trzech mostów, dwóch wiaduktów, } \\
\text { dwóch rond, } 300 \mathrm{~m} . b \text {. estakad, } 700 \mathrm{~m} . b \text {. ekranów, do- } \\
\text { datkowe odwodnienie i pompowanie. }\end{array}$ \\
\hline Konserwatorski & $\begin{array}{l}\text { Nie będzie wyburzeń budynków mieszkalnych, } \\
\text { a jedynie tych, które nie podlegają ochronie kon- } \\
\text { serwatorskiej (obiekty gospodarcze przy nasy- } \\
\text { pie kolejowym). }\end{array}$ & \begin{tabular}{|l} 
- Inwestor i autorzy koncepcji nie wystąpili na etapie \\
planowania trasy o wstępne uzgodnienie do Woje- \\
wódzkiego Konserwatora Zabytków (wymagane jest \\
to także w przypadku specustawy). \\
- Droga będzie przebiegać bardzo blisko budynków (też \\
zabytkowych), co może prowadzić do ich uszkodzeń.
\end{tabular} \\
\hline $\begin{array}{l}\text { Krajobrazowy } \\
\text { i turystyczny }\end{array}$ & $\begin{array}{l}\text { - Jedynym elementem infrastruktury drogowej } \\
\text { mogącym mieć wpływ na percepcję krajobrazu } \\
\text { będą ogrodzenia akustyczne. }\end{array}$ & $\begin{array}{l}\text { - Zubożenie atrakcji turystycznej, jaką jest wyspa Pa- } \\
\text { sieka i Park Nadodrzański. }\end{array}$ \\
\hline Polityczny & - Obietnica wyborcza prezydenta Opola. & $\begin{array}{l}\text { - W opinii radnych opozycyjnych władze miasta wyko- } \\
\text { nują ruchy pozorne, bo Opola nie stać na budowę tej } \\
\text { trasy. }\end{array}$ \\
\hline Społeczny & $\begin{array}{l}\text { - Na sprawę budowy średnicówki należy patrzeć } \\
\text { z perspektywy interesu całego miasta. }\end{array}$ & - Budowa trasy spowoduje znaczne konflikty społeczne. \\
\hline $\begin{array}{l}\text { Etyczny } \\
\text { i emocjonalny }\end{array}$ & \begin{tabular}{|l|} 
- Kilkadziesiąt osób nie może blokować tej budo- \\
wy i odcinać 45 tys. osób z zachodniej części \\
Opola od szkól, szpitali, straży i pogotowia.
\end{tabular} & $\begin{array}{l}\text { - Park Nadodrzański to skarb należący do całego mia- } \\
\text { sta, nastąpi degradacja tkanki miejskiej, z której ko- } \\
\text { rzystają wszyscy mieszkańcy Opola. }\end{array}$ \\
\hline
\end{tabular}

Źródło: opracowanie autora. 


\section{PODSUMOWANIE}

Rozpatrując konflikt wokól planów budowy trasy średnicowej z punktu widzenia pytań badawczych wydaje się, że z punktu widzenia prawa władze Opola wypełniły przesłanki formalne. Dodatkowo ze względu na wage sprawy włodarze miasta zorganizowali nieobligatoryjne konsultacje o charakterze lokalnego referendum. Wzięło $\mathrm{w}$ nich udział ponad 20 tys. osób, co stanowi niemal 1/5 ówczesnej liczby mieszkańców. Pozwoliły one zainteresowanym stronom na szeroką prezentację swoich racji, czego dowodzą chociażby informacje zawarte $\mathrm{w}$ tab. 2. Wypełniono tym samym następujące zasady katalogu "dobrych praktyk": legalności, reprezentatywności, przejrzystości oraz dobra społecznego i interesu ogólnego (chociaż tę ostatnią wartość każda ze stron postrzega inaczej).

Nie zrealizowano natomiast bardzo ważnej zasady rzetelności - nie zapewniono pełnego dostępu do informacji, nie wykazano w ulotkach informacyjnych wad planowanych inwestycji, nie zadbano o niezależnych obserwatorów przebiegu konsultacji, umieszczono drzewa przeznaczone do wycinki na prezentowanych $\mathrm{w}$ ramach kampanii informacyjnej wizualizacjach, przedstawiono niezaktualizowany projekt trasy (w którym wykazano mniejszą niż faktyczna liczbę wiaduktów do budowy i przedstawiono niższe od zakładanych, po uwzględnieniu poprawek, koszty). Naruszono również zasadę dobrej wiary - część mieszkańców Opola odrzuciła wynik konsultacji, uważając, że stanowiły one instrument wzmocnienia decyzji Ratusza.

Wydaje się, że działania władz przyniosły efekt odwrotny od oczekiwanego. Nie udało się osiągnąć porozumienia, a ci mieszkańcy Opola, którzy kwestionują uczciwość i rzetelność przeprowadzenia konsultacji, nadal starają się zablokować inwestycję. Robią to wykorzystując niedociągnięcia i błędy inwestora oraz nieprecyzyjne zapisy $\mathrm{w}$ decyzji środowiskowej. Stowarzyszenie KOP - Miasto dla Ludzi oraz organizacje ekologiczne odwołały się do wyższych instancji, a w razie przegranej zapowiadają postępowania sądowe. Nie ulega wątpliwości, że Stowarzyszanie KOP - Miasto dla Ludzi odgrywa rolę ruchu miejskiego i pełni kluczową funkcję $\mathrm{w}$ działaniach związanych $\mathrm{z}$ protestem wobec trasy średnicowej. Gdyby nie zaangażowanie merytoryczne i finansowe (ulotki, ogłoszenie prasowe, materiały wykorzystywane w happeningach) członków tej organizacji, a także umiejętność pozyskiwania sojuszników - postęp $\mathrm{w}$ realizacji inwestycji byłby znacznie szybszy (obecnie zatrzymał się na etapie postępowania środowiskowego). Niebagatelne znaczenie ma również wyjście KOP - Miasto dla Ludzi poza ramy konfliktu typu NIMBY (z ang. not in my back yard - w tlumaczeniu na pol.: „nie na moim podwórku") i przekonanie części mieszkańców Opola, że spór nie dotyczy walki o estetykę własnego otoczenia, ale zieleni miejskiej, prawa obywateli do odpoczynku i rekreacji, czystego powietrza. Podobne spostrzeżenia ma Michałowska, która analizując konflikty zwane syndromem NIMBY uznała, że nie były one jedynie "wyrazem organizowania się różnych typów społeczności lokalnych wobec dotykających je procesów", ale także wpłynęły „na wzrost aktywności lokalnej, wykształcily nowe kanały społecznej komunikacji, wykreowały liderów" (Michałowska, 2008, s. 79-80).

Od momentu przełomu ustrojowego w Polsce dużo mówi się o społeczeństwie obywatelskim i partycypacji społecznej. Jednak, jak się okazuje, obowiązujące prawo nie ułatwia obywatelom udziału $\mathrm{w}$ procesie uchwalania dokumentów planistycznych. Wynika to z niedoprecyzowania ustawowych przepisów prawnych m.in. w zakresie prawidłowego przeprowadzenia konsultacji, z niezbyt korzystnego dla obywateli orzecznictwa sądów administracyjnych oraz z braku przychylnego i konstruktywnego podejścia niektórych włodarzy samorządowych. W konsekwencji konsultacje mają charakter pozorny, a ich wyniki budzą ogromne rozczarowanie. A przecież konsultacje społeczne nie powinny być traktowane przez władze samorządowe jak zrealizowanie uciążliwego obowiązku czy możliwość potwierdzenia (czasem w niezbyt rzetelny sposób) swoich racji. Wręcz przeciwnie, mają podnosić świadomość odpowiedzialności za decyzje podejmowane na rzecz wspólnoty lokalnej. Dlatego należy zgodzić się z opinią Towarzystwa Urbanistów Polskich - Oddział w Warszawie, że tylko „wysoka jakość merytoryczna konsultacji i forma przyjazna wszystkim mieszkańcom pozwoli na faktyczny udział w podejmowaniu decyzji o ich przestrzeni" (Kolipiński, 2014, s. 6).

Potrzebne jest zatem nowe prawo o planowaniu przestrzennym, które $\mathrm{w}$ znacznie szerszym zakresie oraz na wcześniejszych etapach włączałoby mieszkańców w akt tworzenia wspólnej przestrzeni. Jednak i bez zmian aktów prawnych warto, aby władze samorządowe zapraszały obywateli do udziału $\mathrm{w}$ warsztatach związanych $\mathrm{z}$ modelowaniem przestrzeni (wzrost aktywności społecznej, ale także uświadomienie barier związanych z planowaniem).

Konsultacje społeczne powinny być poprzedzone szeroką akcją informacyjną. Przedstawiane ma- 
teriały muszą mieć zrozumiały dla obywateli, rzetelny i merytoryczny charakter. Przepisy samorządowe winny uwzględniać możliwość zaskarżenia trybu przeprowadzenia konsultacji. Prezentowane wizualizacje muszą opierać się na przewidywanych skutkach realizacji projektu, a nie tworzyć graficzną iluzję przyszłości, która nie zostanie urzeczywistniona. Warto, aby obywatelskie debaty miały różnorodny charakter, moga np. polegać na spotkaniach władz $\mathrm{z}$ grupami bezpośrednio związanymi z projektem czy partnerskich dyskusjach z wybranymi przez mieszkańców przedstawicielami. Najmniej potrzebna jest natomiast debata polegająca na przedstawieniu informacji przez grono urzędników i ekspertów, podczas której odrzuca się wszelkie argumenty obywateli.

\section{BIBLIOGRAFIA}

Adamska, M.E. (2016). Odrzańskie wyspy Opola - Bolko i Pasieka. Historia, rozwój przestrzenny i walory krajobrazu. Prace Komisji Krajobrazu Kulturowego, 33, s. 137-153.

Angrosino, M. (2010). Badania etnograficzne i obserwacyjne. Warszawa: Wydawnictwo Naukowe PWN.

Arnstein, S.R. (2012). Drabina partycypacji. W: Partycypacja. Przewodnik krytyki politycznej (s. 12-19). Warszawa: Wyd. Krytyka Polityczna.

Billert, A. (2013). Likwidacja podmiotowości miast i ich degradacja jako wynik btędnej polityki rozwoju państwa, http://zielonewiadomosci.pl/wpcontent/uploads/2012/01/Billert _Likwidacja_podmiotowosci_miast.pdf

Czarnik, Z. (2017). Ochrona interesów społeczności lokalnej i gminy w planowaniu przestrzennym. W: Z. Kmieciak (red.), Partycypacja w postępowaniu administracyjnym. W kierunku uspołecznienia interesu prawnego (s. 169-192). Warszawa: Wolters Kluwer Polska.

Długosz, D., Wygnański, J.J. (2005). Obywatele wspótdecydują. Przewodnik po partycypacji spotecznej. Warszawa: Stowarzyszenie na rzecz Forum Inicjatyw Pozarządowych.

Dmochowska-Dudek, K. (2014). Konflikty społeczno-przestrzenne jako nowy przedmiot badań geografii społecznej W: W. Maik, K. Rembowska, A. Suliborski (red.), Podstawowe idee $i$ koncepcje w geografii. Dorobek polskiej geografii po konferencji w Rydzynie. Ocena krytyczna. T. 8 (s. 143-153). Łódź: Wyd. Uniwersytetu Łódzkiego.

Dubisz, S. (red.), 2006, Uniwersalny stownik języka polskiego. Warszawa: Wydawnictwo Naukowe PWN

du Wall, M., Walecka-Rynduch, A. (2012). Wyzwania komunikacyjne wobec polityki protestu (PR w ruchach społecznych i ruchach protestu). W: G. Piechota, (red.), Public relations wobec wyzwań wspótczesności (s. 43-68). Kraków: Krakowska Akademia Andrzeja Frycza Modrzewskiego.

Dutkowski, M. (1995). Konflikty w gospodarowaniu dobrami środowiskowymi. Rozprawy i Monografie, 215, Gdańsk: Wyd. Uniwersytetu Gdańskiego.

Fiedziukiewicz, K. (2008). Udziat społeczeństwa w planowaniu przestrzennym. Aspekty prawne, http://pspe.gridw.pl/?id=11

Grochowska, A. (2016). Konflikty przestrzenne w planowaniu przestrzennym obszarów metropolitarnych na przykładzie Wrocław- skiego Obszaru Metropolitarnego. Wrocław: Uniwersytet Wrocławski.

Hajduk, S. (2010). Stan zaawansowania planowania przestrzennego w gminach województwa podlaskiego. Studia Regionalne i Lokalne, 1 (39), s. 105-115.

Hausner, J. (red.) (1999). Komunikacja i partycypacja spoteczna: poradnik. Kraków: Małopolska Szkoła Administracji Publicznej Akademii Ekonomicznej.

Herbst, K. (2014). Partycypacja a prawo do miasta. W: Partycypacja spoteczna w planowaniu przestrzennym. Konferencja Towarzystwa Urbanistów Polskich Oddziału w Warszawie oraz Biura Architektury i Planowania Przestrzennego Urzędu m.st. Warszawy (s. 16-32). Warszawa: Towarzystwo Urbanistów Polskich, Oddział w Warszawie.

Jabłoński, W., Mazurkiewicz, K. (2014). Konflikty przestrzenne na terenach wiejskich - ignorancja czy niewiedza? Studium przypad$k u$. „Infrastruktura i ekologia terenów wiejskich”, IV/2. Kraków: Polska Akademia Nauk, s. 1167-1177.

Jadach-Sepioło, A. (2018). Gminny program, rewitalizacji. Praktyczny poradnik dla mieszkańców i władz lokalnych. Warszawa: Krajowy Instytut Polityki Przestrzennej i Mieszkalnictwa.

Kikosicka, K. (2014). Partycypacja społeczności lokalnej w planowaniu przestrzennym. Acta Universitatis Lodziensis. Folia Geographica Socio-Oeconomica, 16, s. 97-113.

Kmieciak, Z. (2017). Problemy i wyzwania partycypacji w postępowaniu administracyjnym. W: Z. Kmieciak (red.), Partycypacja w postępowaniu administracyjnym. W kierunku uspotecznienia interesu prawnego (s. 17-45). Warszawa.

Kolipiński, B. (2014). Słowo wstępne. W: Partycypacja społeczna w planowaniu przestrzennym. Konferencja Towarzystwa Urbanistów Polskich Oddziatu w Warszawie oraz Biura Architektury i Planowania Przestrzennego Urzędu m.st. Warszawy (s. 6). Warszawa: Towarzystwo Urbanistów Polskich, Oddział w Warszawie.

Lachiewicz, S., Matejun, M. (2010). Studia przypadków karier menedżerskich absolwentów Politechniki Łódzkiej. W: I. Stec (red.), Ksztatcenie menedżerów na uczelni technicznej (s. 81-107). Łódź: Wyd. Politechniki Łódzkiej.

Małecka-Łyszczek, M. (2014). Partycypacja w ramach public governance. W: B. Dolnicki (red.), Partycypacja społeczna w samorzadzie terytorialnym (s. 44-57). Warszawa: Wolters Kluwer Polska.

Marchaj, R. (2014). Samorzadowe konsultacje spoteczne. Warszawa: Wolters Kluwer Polska.

Matejun, M. (2011). Metoda studium przypadku w pracach badawczych młodych naukowców z zakresu nauk o zarządzaniu. Zeszyty Naukowe Uniwersytetu Szczecińskiego, 666. Problemy Zarządzania, Finansów i Marketingu, 19, s. 203-213.

Michałowska, E. (2008). Syndrom NIMBY jako przykład samoorganizacji społecznej na poziomie lokalnym. Studia Regionalne i Lokalne, 6, s. 60-80.

Niżnik-Dobosz, I. (2014). Partycypacja jako pojęcia i instytucja demokratycznego państwa prawnego i prawa administracyjnego. W: B. Dolnicki (red.), Partycypacja spoteczna w samorządzie terytorialnym. Warszawa: Wolters Kluwer Polska, s. 21-43.

Olejniczak, P. (2015). Partycypacja społeczna jako podstawa społeczeństwa obywatelskiego. Prace Naukowe Wyższej Szkoty Zarządzania i Przedsiębiorczości, 31, Wałbrzych, s. 111-121.

Piec, J. (2009). Partycypacja spoteczna w procesie planowania $i z a-$ gospodarowania przestrzeni, https://www.prawo.pl/biznes/ partycypacja-spoleczna-w-procesie-planowania-i-zagospoda rowania-przestrzeni, 143767.html

Pröpper, I. (2000). Interactive policy making: Opportunity or risk for local democracy. Referat wygłoszony na konferencji pt. 
„Interactive governance: Towards a postparliamentary local democracy", Enschede, 9-10.10.

Sadura, P. (2012). Za obywatelskie zaangażowanie trzeba płacić. W: Partycypacja. Przewodnik Krytyki Politycznej (s. 40-50). Warszawa: Wyd. Krytyka Polityczna.

Schimanek, T. (2015). Partycypacja obywatelska w społeczności lokalnej. Warszawa: Fundacja Inicjatyw Społeczno-Ekonomicznych.

Siemieński, W. (2016). Partycypacja społeczna w planowaniu przestrzennym jako element polityki miejskiej. Człowiek $i$ Środowisko, 40, s. 77-93.

Szlachetko, J.H. (2017). Partycypacja społeczna w lokalnej polityce przestrzennej. Warszawa: Wolters Kluwer Polska.

Tokajuk, J. (2011). Konflikty przestrzenne na styku istniejącej zabudowy zagrodowej i planowanej zabudowy mieszkaniowej na terenach wsi strefy podmiejskiej włączonych do obszaru miasta Białegostoku. Przestrzeń i Forma, 15, s. 311-320.

Weber, M. (1985). „Obiektywność” poznania w naukach społecznych. Warszawa: PSW.

Wójcicki, M. (2014). Pojęcie, istota i formy partycypacji społecznej w procesie planowania przestrzennego. Rozwój Regionalny i Polityka Regionalna, 24, s. 169-183.

Zachariasz, I. (2014). Partycypacja w procesie planowania przestrzennego jako prawo podmiotowe. W: Partycypacja spoteczna w planowaniu przestrzennym. Konferencja Towarzystwa Urbanistów Polskich Oddziatu w Warszawie oraz Biura Architektury i Planowania Przestrzennego Urzędu m.st. Warszawy (s. 7-15). Warszawa: Towarzystwo Urbanistów Polskich, Oddział w Warszawie.

\section{Artykuły prasowe}

Guzik, P. (2018). Trasa średnicowa w Opolu nadal w zawieszeniu. Miasto nie zawnioskowało do GDOŚ o wznowienie postępowania środowiskowego. Nowa Trybuna Opolska z 10.12. http:/ / opole.naszemiasto.pl/artykul/trasa-srednicowa-wopolu-nadal-w-zawieszeniu-miasto-nie,4914512,artgal,t,id, tm.html (dostęp: 3.01.2019).

Guzik, P. (2019). Trasa średnicowa przez Pasiekę w Opolu. Miejski Zarząd Dróg zawnioskował o odwieszenie postępowania środowiskowego. Nowa Trybuna Opolska z 5.09., https:/ /opole naszemiasto.pl/trasa-srednicowa-przez-pasieke-w-opolumiejski-zarzad-drog/ar/c1-7324797?kategoria=1

Janowski, A. (2015a). Miłośnicy autobusów przeciwko drodze na Pasiece. Nowa Trybuna Opolska z 14.07., https://nto.pl/ milosnicy-autobusow-przeciwko-drodze-na-pasiece/ar/ 6208830

Janowski, A. (2015b). Opolski PiS przeciwko budowie drogi na Pasiece. Nowa Trybuna Opolska z 17.07., https:/ /nto.pl/opolski -pis-przeciwko-budowie-drogi-na-pasiece-wideo/ar/6209028

Janowski, A. (2015c). Opolanie protestowali przeciwko drodze przez Pasiekę. Nowa Trybuna Opolska z 19.07., https:/ / nto.pl/ opolanie-protestowali-przeciwko-drodze-przez-pasiekewideo-zdjecia/ar/6209160.

Janowski, A. (2015d). Prezydent Opola będzie czekać na opolan Nowa Trybuna Opolska z 14.09., https://nto.pl/prezydentopola-bedzie-czekac-na-opolan/ar/8009373

Janowski, A. (2015e). Konserwator zabytków przeciwko trasie na Pasiece. Nowa Trybuna Opolska z 15.09., https://nto.pl/ konserwator-zabytkow-przeciwko-trasie-na-pasiece/ar/ 8010636

Janowski, A. (2015f). Szykuje się blokada mostu Piastowskiego w Opolu. Nowa Trybuna Opolska z 15.10., https://nto.pl / szykuje-sie-blokada-mostu-piastowskiego-w-opolu-wideo /ar/8997095
Janowski, A. (2015g). Trasa średnicowa czy obwodnica południowa? Ratusz ma trzy pytania dla opolan. Nowa Trybuna Opolska z 15.10., https://nto.pl/trasa-srednicowaczy-obwodnica-poludniowa-ratusz-ma-trzy-pytania-dla -opolan/ar/8997955

Janowski, A. (2015h). Trasa średnicowa w Opolu. MZD modyfikuje koncepcję. Nowa Trybuna Opolska z 21.10., https://nto $\mathrm{pl}$ /trasa-srednicowa-w-opolu-mzd-modyfikuje-koncepcje/ ar/9017149

Janowski, A. (2015i). Dodatkowe pieniądze na trasę średnicową w Opolu. Nowa Trybuna Opolska z 3.11., https://nto.pl/ dodatkowe-pieniadze-na-trase-srednicowa-w-opolu/ar/ 9052175

Janowski, A. (2015j). Nowe pomysły na most przez Odrę w Opolu. Nowa Trybuna Opolska z 9.11., https://nto.pl/nowe -pomysly-na-most-przez-odre-w-opolu-mapa/ar/9068789

Janowski, A. (2015k). Blokady mostu Piastowskiego nie będzie. Wniosek zbyt późno wpłynął do ratusza. Nowa Trybuna Opolska z 16.10., https:/ / nto.pl/blokady-mostu-piastowskiegow-opolu-nie-bedzie-wniosek-zbyt-pozno-wplynal-do-ratusza/ ar/9001688

Janowski, A. (2016). Nie chcą trasy średnicowej na Pasiece. Nowa Trybuna Opolska z 3.07., https://nto.pl/nie-chca-trasysrednicowej-na-pasiece-zdjecia-wideo/ar/10364366

Janowski, A. (2017a). Budowa trasy średnicowej w Opolu wciąż niepewna. Nowa Trybuna Opolska z 26.04., https://nto.pl/ budowa-trasy-srednicowej-w-opolu-wciaz-niepewna/ar/ 12023192

Janowski, A. (2017b). Trasa przez Pasiekę nie ma sensu? Nowa Trybuna Opolska z 5.06., https://nto.pl/trasa-przez-pasiekenie-ma-sensu-wideo/ar/12147843

Janowski, A. (2017c). Rybczyński: - Trasa średnicowa jest Opolu potrzebna. Nowa Trybuna Opolska z 27.06., https://nto.pl/ rybczynski-trasa-srednicowa-jest-opolu-potrzebna/ar/ 12199931

Janowski, A. (2017d). Droga przez Pasiekę wyłącznie na papierze. Nowa Trybuna Opolska z 11.09., https:/ / plus.nto.pl/droga -przez-pasieke-wylacznie-na-papierze/ar/12467666

Janowski, A. (2018). Trasa średnicowa w Opolu oficjalnie zawieszona. Nie wiadomo, czy kiedykolwiek powstanie. Nowa Trybuna Opolska z 15.04., https:/ / nto.pl/trasa-srednicowa-w -opolu-oficjalnie-zawieszona-nie-wiadomo-czy-kiedykolwiekpowstanie/ar/13094736

\section{Dokumenty}

Przeprawy odrzańskie w Opolu. Trasa średnicowa. Trasa Bolkowska. Obwodnica południowa. Papier negocjacyjny powstał w ramach Debaty Obywatelskiej „Docelowy układ komunikacyjny miasta Opola" prowadzonej od 2011 roku. (2012). Opole: Silesia.

RDOŚ: decyzja z 5.07.2016 r. dotycząca środowiskowych uwarunkowań dla przedsięwzięcia pn. „Budowa trasy średnicowej $w$ ramach zadania - budowa przeprawy przez rzekę Odrę wraz z drogami dojazdowymi i obiektami umożliwiającymi włączenie do układu komunikacyjnego miasta Opola" w wariancie IIA wnioskowanym do realizacji.

Uchwała nr XLI/424/04 Rady Miasta Opola z 29 grudnia 2004 r. w sprawie zasad i trybu przeprowadzania konsultacji z mieszkańcami miasta Opola.

Uchwała nr LXII/695/06 Rady Miasta Opola z 6 kwietnia 2006 r. w sprawie przystąpienia do sporządzenia m.p.z.p.

Uchwała nr XIX/173/07 Rady Miasta Opola z 25 października 2007 r. w sprawie uchwalenia miejscowego planu zagospo- 
darowania przestrzennego „Śródmieście I - wyspa Pasieka” w Opolu.

Uchwała nr LXXI/745/10 Rady Miasta Opola z 26 sierpnia 2010 r. w sprawie uchwalenia zmiany „Studium uwarunkowań i kierunków zagospodarowania przestrzennego miasta Opola".

Uchwała nr LXVI/1248/18 Rady Miasta Opola z 5 lipca 2018 r. o uchwaleniu "Studium uwarunkowań i kierunków zagospodarowania przestrzennego Opola".
Ustawa z 8.03.1990 r. o samorządzie gminnym (Dz.U. 1990, nr 16, poz. 95, ze zm.).

Ustawa o planowaniu i zagospodarowaniu przestrzennym z 27.03. 2003 r. (Dz.U. z 2018, poz. 1945 ze zm.).

Ustawa o rewitalizacji (u.r.) z 9 października 2015 r. (Dz.U. nr 2015, poz. 1777).

Zarządzenie Prezydenta Miasta Opola nr OR-I.0050.457.2015 z 2.09.2015.

Artykuł wpłyną:

23 sierpnia 2019

Zaakceptowano do druku:

3 listopada 2019 